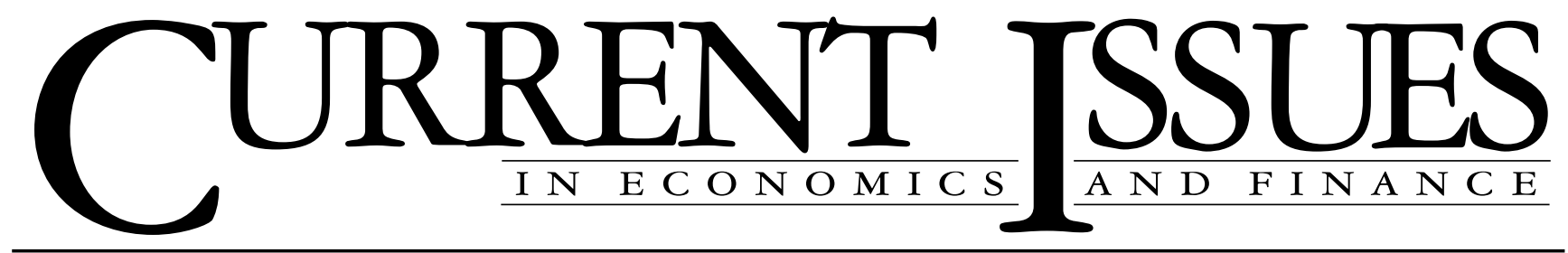

April 1996

Volume 2 Number 5

\title{
1996 Job Outlook: The New York-New Jersey Region
}

James Orr and Rae D. Rosen

The New York-New Jersey region's hard-earned recovery in employment is being overshadowed by ongoing job losses in certain sectors and the prospect of moderating growth in the United States as a whole. Fortunately, several positive trends are bolstering the region's employment picture. Strength in the services sector, a falloff in restructuring, and gains in income point to continuing — though modest—regional job growth in 1996.

U.S. economic growth is expected to moderate mildly in 1996 as the nation's expansion matures. ${ }^{1}$ This slowing comes in the fourth year of the New York-New Jersey region's recovery from its steep 1989-92 downturn. Like other measures of the region's economic vitality, job growth has improved at a very modest pace over the last three years. In 1995, it was just under 1.0 percent, slightly below the rate achieved in previous recoveries.

Could a leveling off of the nationwide expansion halt the already tentative job recovery in the New YorkNew Jersey region? Although moderating growth in the United States as a whole is expected to restrain job creation in New York and New Jersey, it is not likely to derail the region's employment recovery. Indeed, although conditions are by no means booming, an analysis of employment trends indicates that the region's job growth is expected to reach 0.8 percent in 1996. These continued modest job gains can largely be attributed to the slackening pace of public and private sector restructurings and to the steady growth in services and income. These developments have put the regional economy on a sounder footing, even as the nation's economy cools. Moreover, the region's relatively weak population and labor force growth should keep the unemployment rate on a downward track throughout the year.
This edition of Current Issues presents the 1996 employment outlook for the region as a whole and for New York State, New York City, and New Jersey individually. We explore current employment trends in the area's five major sectors-finance, manufacturing, government, transportation and public utilities, and services-and assess each sector's potential for generating new jobs in the region.

\section{Job Picture: 1996}

The recovery of employment in New York and New Jersey has been significantly weaker than for the nation, and neither state has yet recouped the jobs lost during its 1989-92 downturn (Chart 1). ${ }^{2}$ Nevertheless, recovery was increasingly evident in both states in 1995, with employment in the region expanding by 0.9 percent. Despite the economic slowing projected for the United States as a whole, our 1996 outlook sees the region maintaining modest job growth of around 0.8 percent, or roughly 90,000 jobs (see table). About two-thirds of these new jobs are expected to be generated in New York and a third in New Jersey, a distribution that reflects the relative size of the two states. The rate of job growth should prove about the same in the two states.

New York and New Jersey's subpar employment performance relative to other regions is not surprising 
in and of itself. Because the region is relatively mature, the pace of job growth here generally lags that in other parts of the country. ${ }^{3}$ In this recovery, however, region-specific developments increased this gap: severe restructuring in the manufacturing and government sectors together shaved 0.3 percentage points off job growth in 1994 and another 0.4 percentage points in 1995, making New York and New Jersey's employment performance among the weakest in the nation. By contrast, Colorado, Florida, and North Carolina, fast-growing states where new job creations more than offset job losses caused by restructurings, recorded employment growth in the range of 3 to 4 percent. Fortunately, the restructurings in manufacturing and government in New York and New Jersey are not expected to constrain growth in 1996 as severely as in 1995. As a result, the region has begun to get back on its feet, and a modest advance in job growth seems highly probable.

The job picture in the region varies substantially across sectors. In the manufacturing and government sectors, job losses will continue, although the rate of loss should ease. To date, planned reductions in state and local government are well below the level of layoffs in 1994 and 1995. Consolidation trends are also expected to keep employment in the utilities and banking sectors under pressure. By contrast, the largest sector, services, will continue to expand, although at a somewhat slower pace. This expansion will help counter some of the losses in other sectors.

To clarify how the region's sectors will fare relative to their national counterparts, we begin the employment outlook for each of the five major sectors with a brief review of U.S. sectoral trends. We then examine

\section{Chart 1}

\section{Recent Trends in Regional Employment}

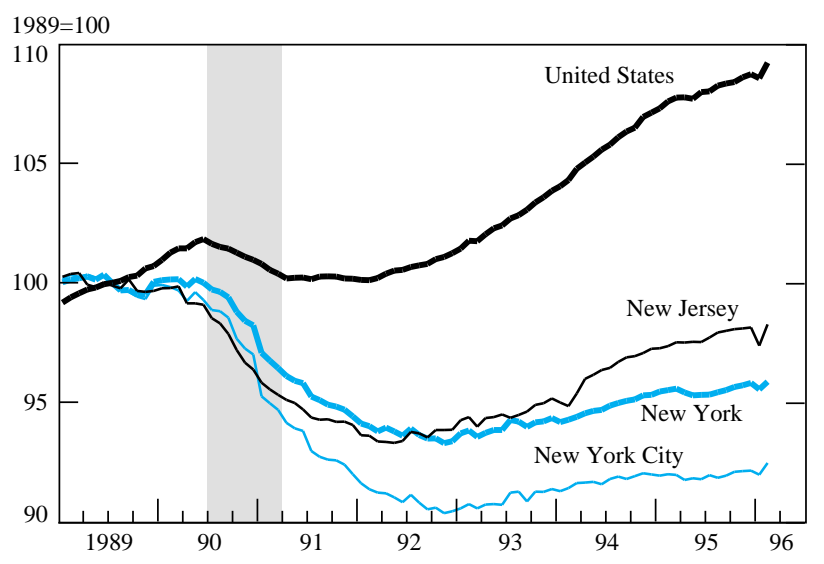

Source: U.S. Department of Labor, Bureau of Labor Statistics.

Notes: The partial government shutdown and the severe weather reduced employment in January 1996. Shaded area denotes a national recession. developments within the region that will influence job growth throughout 1996.

Finance: Weak Job Prospects. For the nation, financial employment is likely to expand moderately in 1996, by slightly more than 1.0 percent, despite ongoing consolidation in the banking industry and restructuring in the insurance industry. ${ }^{4}$ Overall, growth in the securities and brokerage industry, real estate, and other investment advisory services should lead to net gains in total financial employment.

At first glance, the U.S. outlook for the financial industry would seem to bode well for the New YorkNew Jersey region. The area is rich in finance jobs-a large number of the nation's largest banks, brokerage firms, and insurance companies are headquartered in the two states. Fully 30 percent of the nation's brokers work in New York City, and the region commands a disproportionate share of the nation's employment in banking and investment advisory services. The prospects for gains in this sector, however, remain bleak. As has been widely reported, large banks such as Chase Manhattan Bank and Chemical Bank are merging and reducing staff. Moreover, although securities

\section{Employment Forecast for the New York-New Jersey Region}

Annual Percentage Change

\begin{tabular}{lccc} 
& 1994 & 1995 & 1996 \\
\hline New York-New Jersey & 1.1 & 0.9 & 0.8 \\
New York State & 0.8 & 0.7 & 0.8 \\
New York City & 0.6 & 0.2 & 0.5 \\
New Jersey & 1.7 & 1.5 & 0.8 \\
\hline
\end{tabular}

Note: The values for 1996 are projections.

employment is expanding nationally, the trend toward decentralization in this industry is being felt with particular force in the New York-New Jersey region. Retail offices are increasingly being opened in other states because consumer demand for services has grown at a more rapid pace elsewhere in the country. At the same time, some back-office operations are relocating to states with lower operating costs.

All of these factors are likely to produce a moderate decline in aggregate financial employment in New York City and New York State in 1996. Even in New Jersey, where the small securities sector is expanding rapidly, growth is not projected to offset the losses resulting from bank mergers and restructurings in the insurance industry.

Manufacturing: Declines Slowing. Following a nominal gain in 1995, the nation's manufacturing work force is expected to contract as inventory corrections, 
slackening demand, and gains in productivity reduce the need for blue collar labor. Manufacturing employment could decline by as much as 1.0 percent in 1996 .

The New York-New Jersey region, however, seems to be following a different course. In 1995, manufacturing jobs fell about 1.4 percent, despite stability in manufacturing employment nationwide (Chart 2). The decline reflected downsizings and major restructurings in defense-related firms, pharmaceutical companies, and a number of prominent manufacturers in the region, including IBM, Xerox, and Kodak. The expected contraction of the nation's manufacturing work force this year, however, is not projected to lead to greater sectoral job losses in the region. The decline in the number of deep restructurings by manufacturers in New York and New Jersey will help to offset the adverse national effects on regional employment, so that job losses are expected to reach only 14,000 in 1996-about twothirds the number of losses in 1995 and equivalent to a scant 1.0 percent of regional manufacturing employment. These losses will exert less of a drag on overall job growth in 1996.

Within the region, manufacturing employment in New Jersey is expected to be hit somewhat harder than in New York. ${ }^{5}$ Declines in manufacturing jobs are projected to continue across the board, with losses in New Jersey's pharmaceutical and chemical companies weighing down the entire sector. In New York City, the recent revisions in employment figures show that the city lost 7,300 manufacturing jobs in 1995, whereas preliminary data had indicated a gain of more than 3,000 jobs. Combined with a contraction in employment in upstate and western New York (Bram 1996), these losses mean that the long-term decline in manufacturing employment is likely to continue, though at a slower pace.

Government: More Losses. Across the nation, employment is being pared down as Congress attempts to "right size" federal government. At the same time, however, many states and local areas are hiring more workers to service a growing population and handle problems that have devolved to lower levels of government. In 1996, state and local government employment is generally projected to increase roughly 1.0 to 1.5 percent.

Such gains, however, are not expected to show up in the region. In contrast, we expect state and local government employment here to decline in 1996, as New York State, New York City, and, to a much lesser degree, New Jersey attempt to balance slow revenue growth and reductions in taxes. Widening budget gaps have already led to official announcements of job reductions and decreased spending for some programs and services. New York is expected to reduce state employment again this year, bringing the total loss to at least 15,000 jobs over the $1995-96$ period. New York City reduced city payrolls by 22,800 jobs in 1995 ; it is likely to lose at least another 5,000 jobs in 1996 . Although the State of New Jersey hired nearly 8,000 additional employees in 1995, budget considerations may force minor job losses this year.

Transportation and Public Utilities: Restructuring Continues. A variety of industries make up the transportation and public utilities sector, including air, rail, and water transportation; freight handling; transportation services; telecommunications; cable television;

\section{Chart 2}

\section{Weak Sectors in the New York-New Jersey Region}
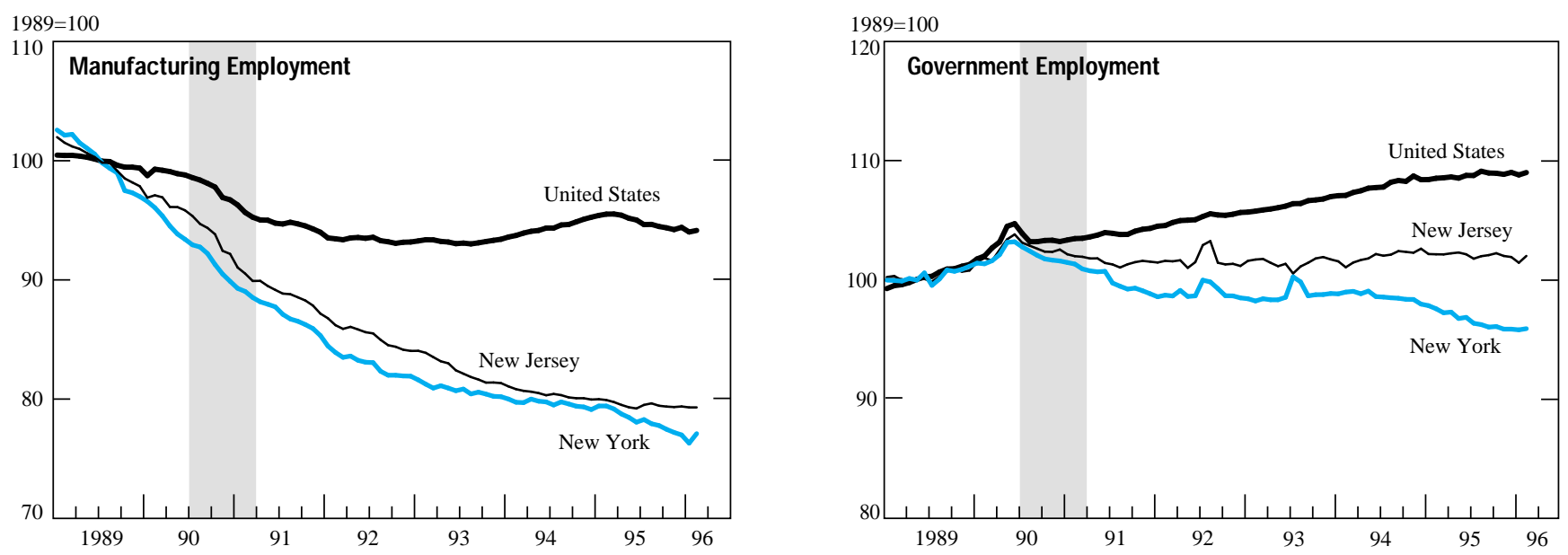

Source: U.S. Department of Labor, Bureau of Labor Statistics.

Notes: The partial government shutdown and the severe weather reduced employment in January 1996. Shaded area denotes a national recession. 
and electric and gas utilities. Dramatic restructurings, new lines of business, and new kinds of business characterize several segments of this sector, particularly the telephone and cable television industries. On balance, job gains will outweigh job losses and, at the national level, employment in this sector is projected to increase a moderate 1.0 to 1.5 percent in 1996 .

In the transportation and public utilities sector in the New York-New Jersey region, more than 5,000 jobs were created in 1995, a gain of almost 1.0 percent. Industries leading job growth included trucking and warehousing, transportation services (for example, ticketing, travel agencies, tours), and the nontelephone segment of the communications industry. In 1996, however, declines of about 7,000 jobs in this sector are forecast for the region. The substantial downsizing at a number of AT\&T facilities in New Jersey is a major source of the decline. PSE\&G, New Jersey's largest electric and gas supplier, has also announced a consolidation. In New York, job losses are expected to continue within the telecommunications industry, but they should slow from their 1995 pace.

Services: Mainstay of Job Growth. Service jobs are the key source of employment growth for the nation (Chart 3). Modest economic growth typically results in increased demand for consumer services such as health care, education, amusement, and recreation and for business services such as advertising, legal counsel, and computers. In 1996, service jobs are generally projected to increase by 2.5 to 3.0 percent at the national level.

Service jobs are also the main contributor to regional job growth. We anticipate gains in regional service employment of around 1.5 to 2.0 percentgood, although not as robust as the nation's gains. Decentralization and the maturity of the New York-New Jersey region limit opportunities for growth. Still, the healthy state of regional income (see box) is helping to create retail jobs. Many smaller industries such as private education, business services, motion pictures, consulting, and wholesale trade will also add jobs and fuel expansion in the service sector.

Job growth in regional health care and social services should also prove moderately strong in 1996, although the rate of growth is likely to slow from the pace of the 1990-95 period (Lowenstein 1995). The slowing largely reflects state and local budget constraints, which are putting pressure on the public monies that fund many of these private services. Changes in the delivery and administration of health care by health maintenance organizations are also easing the pace of demand for health care and social service professionals.

With its heavy concentration of service employment, the New York-New Jersey region might be expected to add service jobs faster than the nation. Two factors will, however, constrain growth in services here. The first is decentralization. The hegemony that the region once held in advertising, law, accounting, and public relations is gradually eroding as firms relocate or decentralize their operations. For example, local companies conducting business abroad consult foreign legal advisors, and several local advertising firms have relocated to states with lower operating costs.

\section{Chart 3}

\section{Growth Sectors in the New York-New Jersey Region}

Percentage Change from Twelve Months Earlier
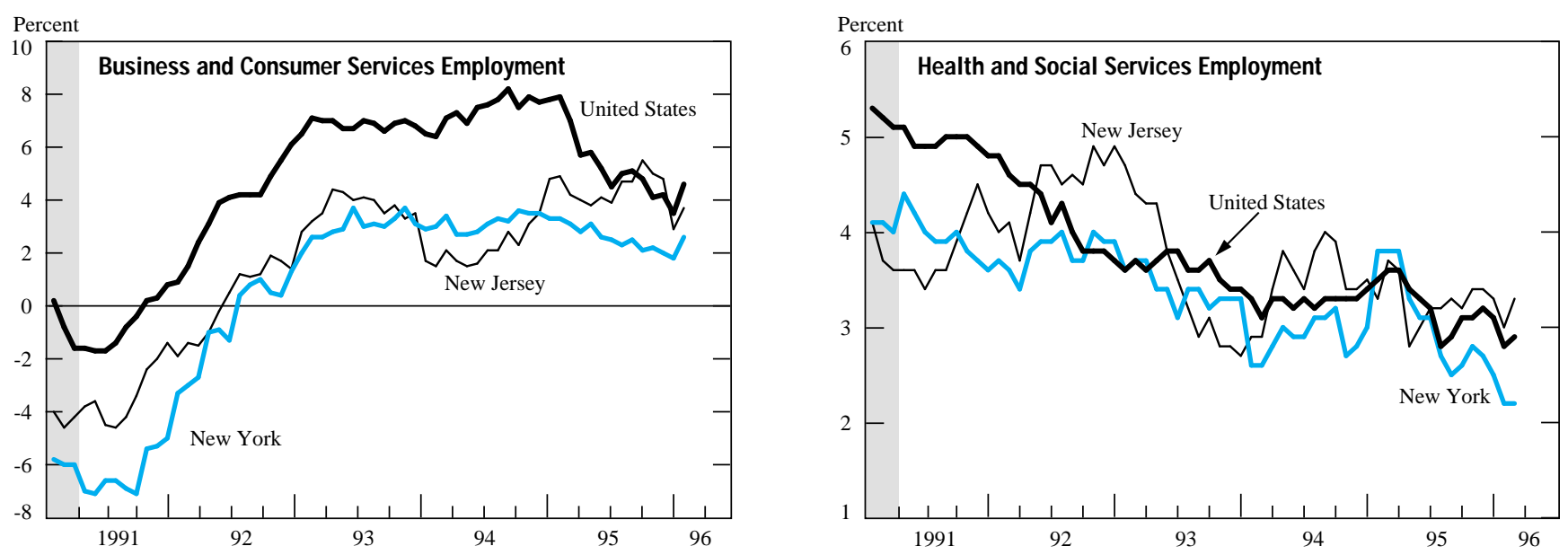

Source: U.S. Department of Labor, Bureau of Labor Statistics.

Notes: The partial government shutdown and the severe weather reduced employment in January 1996. Shaded area denotes a national recession. 
The second constraint is the maturity of the New York-New Jersey marketplace. Important sources of regional job growth such as private education and health care expand more slowly here than at the national level because New York and New Jersey have long-established systems of comprehensive health care and private education. As a result, both sectors command a much larger share of employment in the region relative to the nation and to other states. The existing base and concentration of such jobs as well as the slow rate of population growth in the area limit the potential for future expansion.

\section{Prospects and Risks at the State Level}

Overall, a modestly improved job performance is projected for New York State and New York City in 1996. In New York City, a relatively healthy trade and services sector should offset continued consolidation in the financial sector. In addition, the slower pace of government downsizing should decrease the drag on growth in the private sector this year. New York State job growth will be buoyed by strength in New York City's performance and by a moderate expansion of trade and service jobs statewide. New York State's manufacturing sector is expected to show further-though moderating-declines.

In New Jersey, the rate of job growth, although roughly equal to that of New York State, will slow from its 1995 pace. New Jersey's superior 1995 performance relative to New York was largely the result of sharp cuts in public sector employment in New York State.
Private sector growth rates in New York and New Jersey were not that far apart at 1.3 and 1.8 percent, respectively. In New Jersey, trade, service, and construction jobs will slow from healthy 1995 levels, and manufacturing jobs are expected to continue their decline. Although New Jersey's government sector is likely to experience only minor job losses, projected job declines in commercial banking and at AT\&T are expected to hamper state job growth.

What events could alter our 1996 forecast? Congressional proposals to reduce the budget deficit could have a dramatic impact on state revenues and the health care system in New York and New Jersey, but these effects are more likely to be felt over the longer term. Of more immediate concern are the large budget gaps in New York State and New York City for the upcoming fiscal year. ${ }^{6}$ The prospective gaps have forced the governor of New York State and the mayor of New York City to announce reductions in state and local employment as well as cuts in program spending, and the final job losses may be greater than planned.

\section{Conclusion}

Despite a possible slowing in the nation's recovery and some weak local sectors, the economy of the New York-New Jersey region is expected to record modest job growth of roughly 0.8 percent in 1996 . Given the slow rate of labor force growth in the region-below 0.5 percent-the modest expansion of jobs should be sufficient to push the area's unemployment rate downward throughout 1996.

\section{The Income Picture: Another Measure of Economic Health}

Although the New York-New Jersey region remains one of the lowest ranking U.S. regions in terms of job growth, it has experienced strong income gains in recent years. These gains help to offset the effects of continuing job losses in manufacturing and other sectors. Indeed, it is the strength in income that underlies our projection for relatively healthy growth in services and retail jobs.

How does the region rank in terms of income? New Jersey usually competes with Connecticut for first place in per capita state income. In recent years, New York State has ranked among the top five states. Full data for 1995 income will be available for both states in summer 1996. Preliminary data for New York show that wages, the largest component of income, grew robustly in the first six months of 1995. Nonfinancial wages overall rose 7.5 percent in New York State in the first quarter of 1995 as wages increased sharply in each major industry. The finan- cial sector reported gains of 25 percent in New York State and 40 percent in New York City. In New Jersey, nonfinancial wages rose 5.4 percent in the first quarter of 1995, while financial wages rose 12 percent. We estimate New York-New Jersey's growth in personal income to range from 6.0 to 7.0 percent, compared with an annual average gain of 2.9 percent in U.S. wage rates and a 6.7 percent annual gain in personal income.

Thus, although job growth, an important barometer of economic health, remains low, income levels in New York and New Jersey are high and income growth is reasonably strong. This trend is likely to continue throughout 1996. Compensation got off to a promising start with a boost from large bonus payments-close to $\$ 2$ billion in the banking and securities industries. These moderately strong gains in income figure importantly in our forecast for job growth in 1996. 
Where will the region experience the strongest growth? A sectoral analysis shows that business, consumer, and health services are likely to be major sources of new jobs in the region. Nevertheless, although job growth in these sectors is expected to be relatively strong, decentralization trends and the maturity of the region's marketplace are likely to keep gains at roughly one-half the projected rate for the nation.

The news for the area's other sectors is mixed. Consolidations, mergers, and relocations will prevent finance, historically a key sector for the region, from generating new jobs in 1996. Losses in the manufacturing and government sectors will continue at a more modest pace than in 1995 but will still impede growth. The transportation and public utilities sector is also expected to experience job losses, which will reverse the sector's employment gains in 1995.

Clearly, the New York-New Jersey economy is still getting back on its feet from the steep decline at the start of the decade and the industry restructurings of the past several years. Nevertheless, while certain sectors will continue to suffer losses, overall job growth is expected to edge up. Strength in the services sector, a slowdown in restructuring, and gains in income are all cause for optimism.

\section{Endnotes}

1. The Blue Chip Consensus forecast for 1996 puts annual growth in GDP (chain-weighted 1992 dollars) at 1.9 percent, down from an estimated 2.1 percent in 1995 (Blue Chip Economic Indicators 1996).

2. All regional employment data used in the article are payroll data from the benchmark revisions released in February 1996. The data in Charts 1 and 2 are indexed to compare growth rates of New York

\section{(Endnote 2 Continued)}

and New Jersey with those of the nation. In these two charts, we set employment equal to 100 at the peak of the regional business cycle in 1989 (index 1989=100). Increases in this index represent higher levels of employment relative to the peak, while decreases represent lower levels of employment relative to the peak.

3. Links to the national economy were derived from regressions of quarterly national job growth rates on New York State and New Jersey job growth rates between 1969 and 1995. The regressions yielded coefficients of .76 and .91, respectively. Region-specific factors can influence state growth rates considerably.

4. All sectoral employment projections presented in this article are compiled from several sources, including the WEFA Group and DRI/McGraw-Hill. Our expectations of employment growth in the region are conditional upon the U.S. forecasts.

5. Although the two states are expected to lose a roughly equal number of manufacturing jobs, the proportion of losses differs: the decline is about 1.6 percent of manufacturing employment in New Jersey and about 0.6 percent in New York State.

6. The fiscal year for New York State begins in April 1996; for New York City, July 1996.

\begin{abstract}
References
Blue Chip Economic Indicators. 1996. Vol. 21, no. 3, March 10.

Bram, Jason. 1996. "Dynamics of the Second District Economy." Federal Reserve Bank of New York Current Issues in Economics and Finance 2, no. 2.

DRI/McGraw-Hill. 1996. Review of the U.S. Economy. February.

Lowenstein, Ronnie. 1995. "The Health Sector's Role in New York's Regional Economy." Federal Reserve Bank of New York Current Issues in Economics and Finance 1, no. 5.
\end{abstract}

The WEFA Group. 1996. “U.S. Economic Outlook.” March.

\section{About the Authors}

James Orr and Rae Rosen are senior economists in the Domestic Research Function of the Research and Market Analysis Group.

The views expressed in this article are those of the authors and do not necessarily reflect the position of the Federal Reserve Bank of New York or the Federal Reserve System.

Current Issues in Economics and Finance is published by the Research and Market Analysis Group of the Federal Reserve Bank of New York. Dorothy Meadow Sobol is the editor.

Editorial Staff: Valerie LaPorte, Mike De Mott, Elizabeth Miranda

Production: Graphics and Publications Staff

Subscriptions to Current Issues are free. Write to the Public Information Department, Federal Reserve Bank of New York, 33 Liberty Street, New York, N.Y. 10045-0001, or call 212-720-6134. Back issues are also available. 